\title{
Aldehyde Trapping by ADX-102 Is Protective against Cigarette Smoke and Alcohol Mediated Lung Cell Injury
}

\author{
Carmen A. Ochoa ${ }^{1}$, Claire G. Nissen ${ }^{2}$, Deanna D. Mosley ${ }^{1}$, Christopher D. Bauer ${ }^{1}$, Destiny L. Jordan ${ }^{1}$, \\ Kristina L. Bailey ${ }^{1,3}$ and Todd A. Wyatt ${ }^{1,2,3, *}$ \\ 1 Department of Internal Medicine, College of Medicine, University of Nebraska Medical Center, \\ Omaha, NE 68198-5910, USA; carmen.ochoa@unmc.edu (C.A.O.); deanna.mosley@unmc.edu (D.D.M.); \\ christopher.bauer@unmc.edu (C.D.B.); djordan@creighton.edu (D.L.J.); kbailey@unmc.edu (K.L.B.) \\ 2 Department of Environmental, Agricultural and Occupational Health, College of Public Health, \\ University of Nebraska Medical Center, Omaha, NE 68198-5910, USA; claire.nissen@unmc.edu \\ 3 Veterans Affairs Nebraska-Western Iowa Health Care System, Omaha, NE 68105, USA \\ * Correspondence: twyatt@unmc.edu; Tel.: +1-402-559-3817
}

check for

updates

Citation: Ochoa, C.A.; Nissen, C.G.; Mosley, D.D.; Bauer, C.D.; Jordan,

D.L.; Bailey, K.L.; Wyatt, T.A. Aldehyde Trapping by ADX-102 Is Protective against Cigarette Smoke and Alcohol Mediated Lung Cell Injury. Biomolecules 2022, 12, 393. https: / / doi.org/10.3390/ biom12030393

Academic Editors: Natalia Osna and Kusum K. Kharbanda

Received: 21 December 2021

Accepted: 24 February 2022

Published: 2 March 2022

Publisher's Note: MDPI stays neutral with regard to jurisdictional claims in published maps and institutional affiliations.

Copyright: (C) 2022 by the authors. Licensee MDPI, Basel, Switzerland. This article is an open access article distributed under the terms and conditions of the Creative Commons Attribution (CC BY) license (https:// creativecommons.org/licenses/by/ $4.0 /)$.

\begin{abstract}
Most individuals diagnosed with alcohol use disorders smoke cigarettes. Large concentrations of malondialdehyde and acetaldehyde are found in lungs co-exposed to cigarette smoke and alcohol. Aldehydes directly injure lungs and form aldehyde protein adducts, impacting epithelial functions. Recently, 2-(3-Amino-6-chloroquinolin-2-yl)propan-2-ol (ADX-102) was developed as an aldehyde-trapping drug. We hypothesized that aldehyde-trapping compounds are protective against lung injury derived from cigarette smoke and alcohol co-exposure. To test this hypothesis, we pretreated mouse ciliated tracheal epithelial cells with 0-100 $\mu \mathrm{M}$ of ADX-102 followed by co-exposure to $5 \%$ cigarette smoke extract and $50 \mathrm{mM}$ of ethanol. Pretreatment with ADX-102 dose-dependently protected against smoke and alcohol induced cilia-slowing, decreases in bronchial epithelial cell wound repair, decreases in epithelial monolayer resistance, and the formation of MAA adducts. ADX-102 concentrations up to $100 \mu \mathrm{M}$ showed no cellular toxicity. As protein kinase C (PKC) activation is a known mechanism for slowing cilia and wound repair, we examined the effects of ADX-102 on smoke and alcohol induced PKC epsilon activity. ADX-102 prevented early ( $3 \mathrm{~h}$ ) activation and late $(24 \mathrm{~h})$ autodownregulation of PKC epsilon in response to smoke and alcohol. These data suggest that reactive aldehydes generated from cigarette smoke and alcohol metabolism may be potential targets for therapeutic intervention to reduce lung injury.
\end{abstract}

Keywords: alcohol; cigarette; AUD; acetaldehyde; malondialdehyde; lung

\section{Introduction}

Cigarette smoking is the number one cause of preventable disability and death in the United States, and more than 16 million Americans live with a disease related to cigarette smoking including cancer, heart disease, diabetes, and chronic lung diseases such as COPD and chronic bronchitis [1]. Chronic alcohol use is strongly linked to cigarette smoking. There is a well-established connection between alcohol use and cigarette smoking. More than $80 \%$ of individuals who are alcohol-dependent report that they also smoke cigarettes [2]. As the lung injury effects of polysubstance abuse are understudied [3], it is important to consider the combination effects of alcohol and cigarette use to identify the mechanisms of tissue damage that occur.

Alcohol use has an impact on almost every organ in the body, including the lungs. Individuals who drink heavily are at a higher risk of developing a variety of lung pathologies. Chronic alcohol use increases susceptibility to bacterial pneumonia by impairing the ability of alveolar macrophages to perform phagocytosis [4]. Respiratory syncytial virus (RSV) risk is increased in chronic alcohol users by impeding mucociliary clearance, which 
propels inhaled particles, microbes, toxins, and debris out of the lungs [5]. There is also an increased risk of developing acute respiratory distress syndrome (ARDS) [6].

The majority of alcohol is metabolized in the liver. A small amount is metabolized in the lungs by the alcohol dehydrogenase, CYP2E1. CYP2E1 is especially implicated during chronic alcohol abuse [7] and plays a major role in the oxidant-mediated production of malondialdehyde [8,9]. Volatile aldehydes such as acetaldehyde and malondialdehyde are present in large amounts in cigarette smoke. These aldehydes impair DNA, induce mutagenic adducts, promote lipid peroxidation, and generate reactive oxygen species as well as other free radicals $[8,10,11]$. The combined impact of alcohol and cigarette smoke has unique effects in the airway [12] by covalently modifying proteins and altering inflammatory responses [13]. Acetaldehyde causes lung injury by forming adducts with proteins. Both acetaldehyde and malondialdehyde are associated with the production of reactive oxygen species, which impair the body's ability to detoxify reactive oxygen intermediates and products [8], thereby decreasing mucociliary clearance and leaving pathogens and other environmental debris improperly cleared from the airway.

The lungs' innate defense via mucociliary clearance, which is quantified by cilia beat frequency $(\mathrm{CBF})$, decreases when exposed to cigarette smoke and alcohol in a protein kinase $\mathrm{C}$ epsilon $(\mathrm{PKC} \varepsilon$ ) dose-dependent manner [14]. Cigarette smoke and alcohol stimulate $\mathrm{PKC} \varepsilon$ and inhibit ciliary motility, leading to the slowing of cilia and eventual ciliated cell detachment. PKC $\varepsilon$ is transiently activated 3-6 h after consumption to slow cilia beat frequency. By $24 \mathrm{~h}, \mathrm{PKC} \varepsilon$ is autodownregulated, leading to deciliation and ciliated cell detachment.

ADX-102 is a novel reactive aldehyde species inhibitor that is currently in development for treating dry eye disease. It covalently binds aldehydes to decrease eye inflammation [15]. Due to the high amounts of reactive aldehydes produced in alcohol metabolism and cigarette smoke, this study aimed to use aldehyde trapping to demonstrate the role of aldehydes in smoke and alcohol mediated bronchial epithelial dysfunction. We hypothesized that ADX-102 prevents the activation of PKC isoform activity, thereby decreasing the amount of damage in the airway caused by alcohol and cigarette smoke.

\section{Materials and Methods}

\subsection{Cell Culture}

BEAS-2B, a human bronchial epithelial cell line, cells were obtained from the American Type Culture Collection (ATCC, Manassas, VA, USA). Cell cultures were grown at $37^{\circ} \mathrm{C}$ and 5\% $\mathrm{CO}_{2}$ in M-199 (Gibco, Thermo Fisher Scientific, Waltham, MA, USA) with 10\% fetal bovine serum (FBS) supplemented with penicillin-streptomycin (Gibco, Thermo Fisher Scientific, Waltham, MA, USA) and amphotericin B (Mediatech, Inc., Manassas, VA, USA) in collagen-coated (Invitrogen, Thermo Fisher Scientific, Waltham, MA, USA) tissue culture flasks. A transformed human bronchial epithelial cell line, 16HBE14o-, was obtained from the late D. C. Gruenert (University of California, San Francisco, CA, USA), who cryopreserved low-passage aliquots. Cells were grown in Dulbecco's Modified Eagle Medium (DMEM) with 10\% fetal bovine serum and penicillin-streptomycin supplementation.

For passaging, monolayers were treated with trypsin for $5 \mathrm{~min}$ at $37^{\circ} \mathrm{C}$ for harvesting followed by $10 \%$ FBS to halt the trypsin. Cells were resuspended, counted, and plated at $3 \times 10^{5}$ cells in $800 \mu \mathrm{L}$ per well in 24 well tissue culture plates coated for a minimum of 10 min with $1 \%$ collagen. Cells were left to attach and become $80 \%$ confluent. Prior to experimental treatments, cells were washed with PBS ( $\mathrm{pH} 7.4)$ in fresh medium. Once treatment was added, cells were allowed to incubate at $37^{\circ} \mathrm{C}$ and $5 \% \mathrm{CO}_{2}$ in a standard cell culture incubator (model MCO-19AICUV-PA; Sanyo, Wood Dale, IL, USA). The same incubator was used for all trials.

Using a modified method of that used by Dossou et al. [16], mouse tracheal epithelial cells (MTECs) were cultured using adult wild-type C57BL/ 6 mice that were euthanized via isoflurane inhalation (Sigma-Aldrich, St. Louis, MO, USA). All uses of mice were reviewed and approved by the Institutional Animal Care and Use Committee of the Uni- 
versity of Nebraska Medical Center. Tracheae were dissected and immediately placed in chilled Ham's F-12 Nutrient medium (Thermo Fisher Scientific, Waltham, MA, USA) containing $1.5 \mathrm{mg} / \mathrm{mL}$ pronase (Sigma-Aldrich, St. Louis, MO, USA). The tracheae were left in this solution to dissociate overnight at $4{ }^{\circ} \mathrm{C}$. The dissociated cells were harvested in $0.5 \mathrm{~mL}$ of MTEC basic medium containing Dulbecco's Modified Minimal Essential Medium (DMEM; Invitrogen); F-12 Nutrient mixture, containing glutamine (200 mM/10 mL; Invitrogen), penicillin-streptomycin (10 units, milligrams per milliliter), and gentamycin (50 mg/mL; both purchased from Sigma-Aldrich St. Louis, MO, USA); and amphotericin B (1.25 mg $/ \mathrm{mL}$; Sigma-Aldrich). Cells then incubated for 3.5 hours at $37^{\circ} \mathrm{C}$ in air with $5 \% \mathrm{CO}_{2}$ on $35 \times 10 \mathrm{~mm}^{2}$ Falcon culture dishes (Thermo Fisher Scientific, Waltham, MA, USA). Resuspension of cells was completed in $250 \mathrm{~mL}$ of MTEC-supplemented medium made up of MTEC basic medium, fetal bovine serum (Thermo Fisher Scientific, Waltham, MA, USA), insulin (10 mg/mL), transferrin $(5 \mathrm{mg} / \mathrm{mL})$, recombinant human epidermal growth factor ( $5 \mathrm{mg} / \mathrm{mL}$ ), bovine pituitary extract (Lonza, Rockland, ME, USA), cholera toxin $(62 \mathrm{mg} / \mathrm{mL})$, and retinoic acid (5\%; Sigma-Aldrich St. Louis, MO, USA). Cells were plated at $1 \times 10^{5}$ cells $/ \mathrm{mm}^{2}$ on $6.5 \mathrm{~mm}$ diameter Costar membrane inserts (Corning Life Sciences, Tewksbury, MA, USA); coated with rat tail collagen, type I (Becton Dickinson, Bedford, MA, USA); and allowed to incubate at $37^{\circ} \mathrm{C}$ in air supplemented with $5 \% \mathrm{CO}_{2}$. MTEC-supplemented medium was removed and replaced after 3 days of incubation. When the cultures were confluent (5-6 days), an air-liquid interface (ALI) was established. For ALI, medium was removed from the apical portion of the membrane, resulting in the exposure of the cultures to air on the apical surface and medium on the basal surface. The medium was replaced every 2-3 days until fully formed cilia appeared and exhibited a baseline 10-11 Hz cilia beat frequency.

\subsection{Cell Treatments}

BEAS-2B cells were treated with 1-100 $\mu \mathrm{M}$ ADX-102 diluted in M-199 medium containing $10 \%$ fetal calf serum for up to $24 \mathrm{~h}$ in the presence or absence of $5 \%$ cigarette smoke extract (CSE). Ciliated MTECs were pretreated with $10 \mathrm{nM}$ to $100 \mu \mathrm{M}$ ADX-102 for $1 \mathrm{~h}$, followed by the addition of $50 \mathrm{mM}$ ethanol and 5\% CSE for up to $24 \mathrm{~h}$. 16HBE cells were treated with either $50 \mathrm{mM}$ ethanol, 5\% CSE, or both ethanol and CSE in the presence or absence of $10 \mu \mathrm{M}$ ADX-102 for up to $72 \mathrm{~h}$.

\subsection{Cigarette Smoke Extract Preparation}

Cigarette smoke extract (CSE) was prepared fresh each day using reference cigarettes (85 mm, filtered, 1R6F) that were obtained from the Center for Tobacco Reference Products (CTRP), a division of the Kentucky Tobacco Research \& Development Center at the University of Kentucky (Lexington, KY, USA). Cigarettes were smoked by connecting a cigarette to a peristaltic pump (model ATS-P, Bentley Laboratories, Santa Anna, CA, USA). It was lit and bubbled through $20 \mathrm{~mL}$ of sterile phosphate-buffered saline (PBS, pH 7.4) and equilibrated at a burn rate of $6 \mathrm{~min}$, or $160 \mathrm{~cm}^{3} / \mathrm{min}$. The discharge end of the tube was inserted into the medium in a $50 \mathrm{~mL}$ conical tube, and parafilm was wrapped around the top of it to prevent smoke from escaping. Once approximately $60-75 \mathrm{~mm}$ of the cigarette was burned, the pump was turned off and the medium tube was capped as $100 \%$ CSE. Undiluted CSE medium was sterile-filtered $(0.22 \mu \mathrm{m})$ and diluted into sterile culture medium to a final concentration of $5 \%$ by volume for maximal viability, as reported in [17]. All CSE was used within $12 \mathrm{~h}$ of preparation unless overnight pretreatment was indicated.

\subsection{In Vitro Wound Closure (Migration) Assay}

BEAS-2B cells were grown to confluency in a flat-bottomed, 24-well or $60 \mathrm{~mm}$ tissue culture dish. A circular "wound", approximately $1 \mathrm{~mm}^{2}$, was created within the cell monolayer by a sterile scraper. Differences in rate of wound closure between $60 \mathrm{~mm}$ dishes and 24-well plates were accounted for by adjusting the volume as a ratio of volume to surface area, which created an equipotential rate in wound closure, as described in [18]. 
Migration was monitored with a phase-contrast microscope with a video camera attachment (Olympus, Center Valley, PA, USA). Camera output was captured with image analysis software (NIH ImageJ v1.45 for Mac OS X, Bethesda, MD, USA). Each wound was individually photographed; its images were analyzed at specific time points, and the area of the wound was measured. Dishes remained in the incubator between measurements. The wound area was reduced as cells migrated into it. BEAS-2B cells were grown on $60 \mathrm{~mm}$ tissue culture dishes to confluency for kinase experiments. Using a sterile "cell rake", cell monolayers were wounded, removing cells in a grid-like pattern [19], which removed approximately $14.1 \%$ of total cells. Linear wounds averaged $0.3 \mathrm{~mm}$ in width, $2 \mathrm{~mm}$ apart.

\subsection{PKC $\alpha$ and PKCE Activity Assays}

The conditioned medium from treated cells was removed. Cells were flash-frozen with liquid nitrogen in a cell lysis buffer, as described in [20]. Cells were thawed and removed from the plate with a cell lifter. They were sonicated and centrifuged at $10,000 \times g$ for $30 \mathrm{~min}$ at $4{ }^{\circ} \mathrm{C}$. The soluble cytosolic fraction was collected; the remaining cell pellet was resuspended in cell lysis buffer containing 0.01\% Triton X-100 (Sigma-Aldrich, St. Louis, MO, USA), and the particulate fraction was sonicated again. The isoform activity of PKC was determined in crude lysates by the method previously described in [14]. A reaction mix of $24 \mathrm{mg} / \mathrm{mL}$ PMA, $30 \mathrm{mM}$ dithiotreitol, $150 \mathrm{mM}$ ATP, $45 \mathrm{mM}$ Mg-acetate, PKC isoformspecific substrate peptide (Enzo Life Sciences, Farmington, NY, USA), and $10 \mathrm{mCi} / \mathrm{mL}$ $\left[\gamma^{3}{ }^{32} \mathrm{P}\right]-A T P$ (Perkin Elmer, Waltham, MA, USA) was mixed in a Tris-HCl buffer ( $\left.\mathrm{pH} 7.5\right)$ to measure specific PKC isoform activity. Aliquots $(20 \mu \mathrm{L})$ of cytosolic or particulate fraction were chilled at $4{ }^{\circ} \mathrm{C}$ and added to $40 \mathrm{~mL}$ of the reaction mix and incubated for $15 \mathrm{~min}$ at $30{ }^{\circ} \mathrm{C}$. To halt incubation, a $60 \mu \mathrm{L}$ sample was spotted onto P-81 phosphocellulose paper (Jon S. Oakhill, St. Vincent's Institute of Medical Research, Fitzroy, Australia); then, it was washed 5 times in $75 \mathrm{mM}$ phosphoric acid for $5 \mathrm{~min}$, washed in 100\% ethanol for $1 \mathrm{~min}$, dried, and counted in nonaqueous scintillant (National Diagnostics, Atlanta, GA, USA). PKC activity was expressed in relation to the total amount of cellular protein assayed as picomoles of phosphate incorporated per minute per milligram.

\subsection{Cilia Beating Assay (SAVA)}

Sisson et al. [21] provided an in-depth description and characterization of the SissonAmmons Video Analysis (SAVA) system. This device is used to measure ciliary beat frequency $(\mathrm{CBF})$ of actively beating ciliated cells at a given time point. Motility is quantified by whole-field analysis, which is a combination of phase-contrast microscopy and computerized frequency spectrum analysis. Number of motile points for each $3 \mathrm{~s}$ digital video was determined by a software algorithm in SAVA that assesses the change in light intensity for each 16-pixel zone represented by a $4 \times 4$-pixel area. For every $640 \times 480$-pixel video image, the number of motile zones was calculated from 19,200 possible total zones. Motile points decreased over time as cilia stopped beating or detached from the monolayer.

\subsection{Transepithelial Resistance Assay}

Electric cell-substrate impedance sensing (ECIS, Applied BioPhysics, Troy, NY, USA) was used to determine cell transepithelial electrical resistance (TEER). The 16HBE cell line was used as this cell line produces the greatest barrier resistance in submerged culture monolayers. Cells were grown on collagen-coated 8W1E PET arrays and $5 \times 10^{5}$ cells were plated into each well. They were grown to confluency and treated with different doses of cigarette smoke or ethanol in the presence or absence of ADX-102 (TargetMol, Wellesley Hills, MA, USA) for a maximum of $72 \mathrm{~h}$. Controls consisted of medium-only wells with and without cells. Resistance of cell barriers was measured on the basis of changes in resistance and capacitance to current flow applied to the electrode arrays at $4000 \mathrm{~Hz}$. To test for differences in TEER, resistance values were obtained every $15 \mathrm{~min}$. Baseline was established by comparing changes in resistance over time to wells without either ethanol, cigarette smoke, or a combination of the two with and without ADX-102. 
Background resistance values for a well containing only medium without the presence of a cell monolayer were subtracted.

\subsection{Cell Viability Assay}

A conditioned medium $(50 \mu \mathrm{L})$ was assayed for viability of cells using the provided instructions of a commercially available kit (MAK066-1KT, Sigma-Aldrich, St. Louis, MO, USA) to measure lactate dehydrogenase (LDH) release. Lysed cells were used as a positive control for LDH release. Neither CSE nor alcohol at the concentrations and exposure times used in this study cause cell death $[13,14,17,22]$.

\subsection{ELISA for MAA Adducts}

MAA-adducted proteins were assayed in human BAL samples by indirect competitive ELISA as previously described in [13].

\subsection{Statistical Analysis}

All experiments were performed in triplicate. Each data point represented the mean of a minimum of three independent measurements. Each data point graphically presented in this article represents at least nine measurements used to generate the standard error of the mean. Data were analyzed using Graph Pad Prism (v9.2.0 for Mac, GraphPad Software, San Diego, CA, USA). Data are represented in this paper as mean \pm standard error. Data were analyzed for statistical significance using a two-way ANOVA using Bonferroni or Tukey's multiple comparison posttest corrections, depending on equality of sample sizes between repeated experiments. Significance was accepted at a 95\% confidence interval.

\section{Results}

\subsection{Only High Concentrations of ADX-102 Affect Cell Viability}

ADX-102 use on airway epithelial cells has not been previously reported. To control against any artifacts in cell responses due to toxicity, we treated the bronchial epithelial cell line, BEAS-2B, with various concentrations (up to $10 \mathrm{mM}$ ) of ADX-102 for $24 \mathrm{~h}$ in culture. Then, we collected medium supernates and assayed them for LDH release. No change in the viability $(\geq 95 \%)$ of BEAS-2B cells was observed over this $24 \mathrm{~h}$ period after adding concentrations up to and including $100 \mu \mathrm{M}$ of ADX-102 (Figure 1A). However, a significant decrease in viability was detected in BEAS-2B cells similarly treated with $1 \mathrm{mM}(\leq 84 \%)$ or $10 \mathrm{mM}(\leq 67 \%)$ of ADX-102. Likewise, a significant release of LDH was detected in supernates of $16 \mathrm{HBE}$ cells exposed to $1-10 \mathrm{mM}$ of ADX-102, and there was no detectable increase in LDH observed at or below $100 \mu \mathrm{M}$ (Figure 1B). Treatment up to $72 \mathrm{~h}$ with $>100 \mu \mathrm{M}$ of ADX-102 resulted in no loss in viability. These same results were observed in primary ciliated MTECs (data not shown). No loss of viability due to $5 \%$ cigarette smoke and $50 \mathrm{mM}$ of alcohol treatment $( \pm \leq 100 \mu \mathrm{M}$ ADX-102) was detected in any cell type used.

\subsection{ADX-102 and Wound Repair}

Cigarette smoke impairs the migration of epithelial cells into a wounded monolayer [17]. To examine whether aldehyde trapping impacts the effect of cigarette smoke on epithelial migration, we first determined whether ADX-102 alone alters the migration response of BEAS-2B cells to close a monolayer wound. Compared to a control medium, no change was observed in cell migration in the presence of up to $10 \mu \mathrm{M}$ of ADX-102 (Figure 2A). However, $100 \mu \mathrm{M}$ of ADX-102 resulted in a significant slowing of migration as early as $4 \mathrm{~h}$ after treatment in culture after the monolayer was wounded. In the presence of $5 \%$ CSE, a $1 \mathrm{~h}$ pretreatment with ADX-102 reversed CSE-induced slowing of cell migration into a wound in a dose-dependent manner, and there was a significant difference that occurred with $10 \mu \mathrm{M}$ of ADX-102 (Figure 2B). This response continued for up to $24 \mathrm{~h}$, which was when complete wound closure occurred ( $10 \%$ serum positive control; data not shown). As smoke activation of PKC $\alpha$ is a mechanism for the slowing of epithelial wound repair, and acetaldehyde is a required component of cigarette smoke for PKC activation [22], 
we examined the effect of ADX-102 on CSE-stimulated PKC $\alpha$ activity in BEAS-2B cells. Treatment for $1 \mathrm{~h}$ with $10 \mu \mathrm{M}$ of ADX-102 alone resulted in no change in baseline PKC $\alpha$ activity (Figure 3). CSE (5\%) significantly stimulated PKC $\alpha$ activity by $1 \mathrm{~h}$. However, a $1 \mathrm{~h}$ pretreatment with $10 \mu \mathrm{M}$ of ADX-102 resulted in a significant decrease in CSE-stimulated PKC $\alpha$ activation.
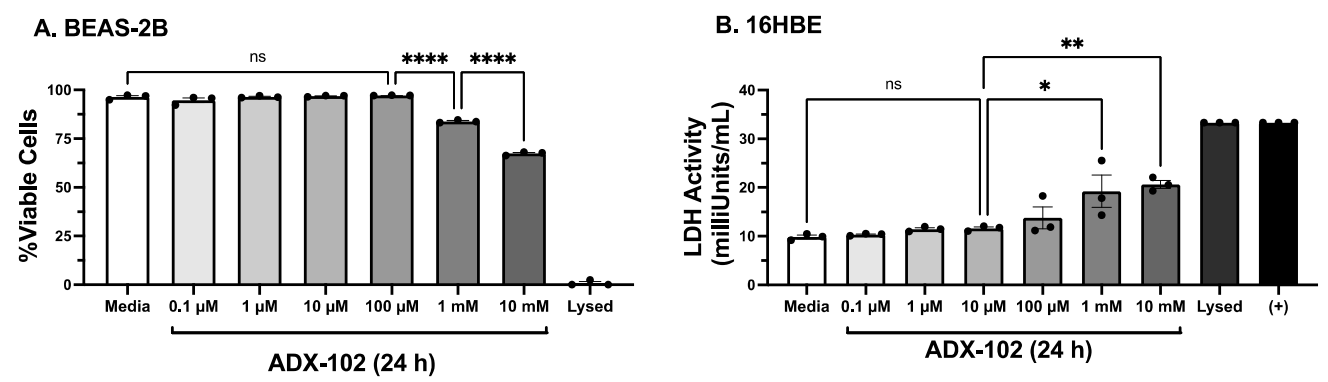

Figure 1. ADX-102 and bronchial epithelial cell viability. Medium release of lactate dehydrogenase (LDH) was measured and expressed as \% viability in BEAS-2B cells (A) or LDH activity in 16HBE cells (B) after $24 \mathrm{~h}$ treatment with $0.1 \mu \mathrm{M}$ to $10 \mathrm{mM}$ ADX-102 in M-199 with $10 \%$ serum (Media). An equal number of cells were sonicated for maximum LDH release (Lysed). Positive assay control (+) was provided by a manufacturer. ${ }^{*} p<0.05$ and ${ }^{* *} p<0.01$ vs. $10 \mu \mathrm{M}$ ADX-102; **** $p<0.0001$ vs. $0-100 \mu \mathrm{M}$ ADX-102. Bars represent SEM of biological $n$ of three with three technical replicates. $\mathrm{ns}=$ not significant.

A

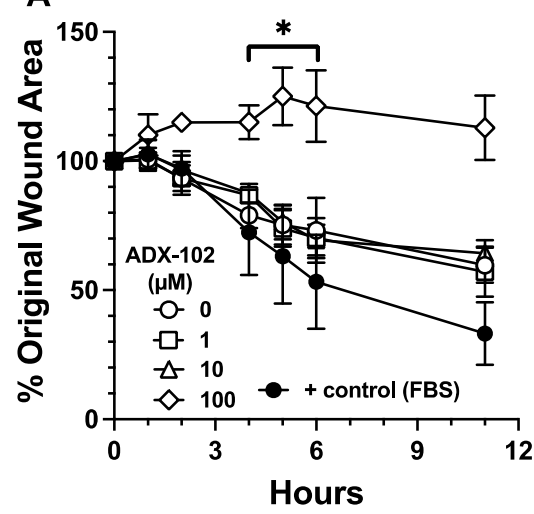

B

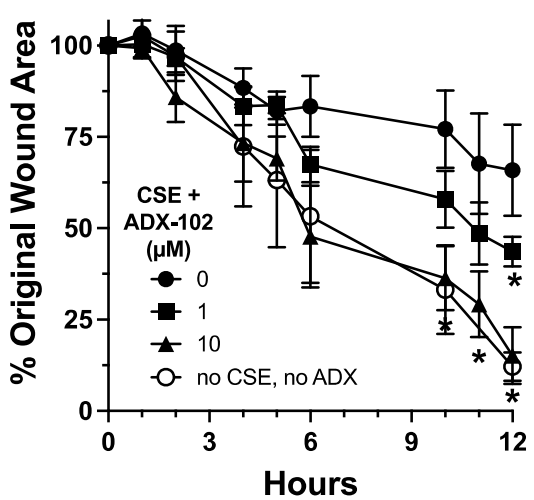

Figure 2. ADX-102 and bronchial epithelial cell migration. Circular wounds in monolayers of BEAS-2B cells were measured for cell migration into the wound area in the presence of $0-100 \mu \mathrm{M}$ ADX-102 over time (A). Positive control for wound closure was M-199 with 10\% serum (FBS). In panel (B), BEAS-2B cells were wounded in the presence of $5 \%$ cigarette smoke extract (CSE) and in the presence of $0-100 \mu \mathrm{M}$ ADX-102, and \% wound closure was measured. ${ }^{*} p<0.05 \mathrm{vs} .0 \mu \mathrm{M}$ ADX-102. Bars represent SEM of $n=5$, each with three replicates.

\subsection{ADX-102 and Cilia Beating}

Cigarette smoke and alcohol co-exposure results in a PKCE-mediated slowing of cilia [14]. To determine if aldehyde trapping impacts this cilia-slowing effect, primary MTECs cultured by air-liquid interface were pretreated for $1 \mathrm{~h}$ with $10 \mu \mathrm{M}$ of ADX-102 prior to combined exposure to $5 \%$ CSE and $50 \mathrm{mM}$ of ethyl alcohol (a biologically relevant and nontoxic dose [14]). Then, CBF was measured. MTECs treated with smoke and alcohol showed significantly decreased CBF (from $11 \mathrm{~Hz}$ to $6 \mathrm{~Hz}$ ) by $3 \mathrm{~h}$ posttreatment, and this decrease was sustained for up to $24 \mathrm{~h}$ (Figure 4A). In the presence of $10 \mu \mathrm{M}$ of ADX-102, a smoke and alcohol mediated decrease in CBF occurred, but it was less pronounced (from $11 \mathrm{~Hz}$ to $8 \mathrm{~Hz}$ ) and the same as that seen in a control medium. By $24 \mathrm{~h}$, smoke and alcohol had no slowing effect on cilia when ADX-102 was present. In the presence of a control medium, CBF was maintained at approximately $11 \mathrm{~Hz}$ for up to $24 \mathrm{~h}$. Concentrations 
of ADX-102 at or below $1 \mathrm{mM}$ produced no significant change from the baseline CBF. Smoke and alcohol rapidly $(3 \mathrm{~h})$ activate $\mathrm{PKC} \varepsilon$, leading to cilia-slowing. Then, PKCE autodownregulates from 6 to $24 \mathrm{~h}$, resulting in kinase activity levels below that of baseline. In the presence of ADX-102 $(1-100 \mu \mathrm{M})$, neither the early $(3 \mathrm{~h})$ activation nor late $(24 \mathrm{~h})$ autodownregulation of $\mathrm{PKC} \varepsilon$ were observed in response to smoke and alcohol (Figure 4B).

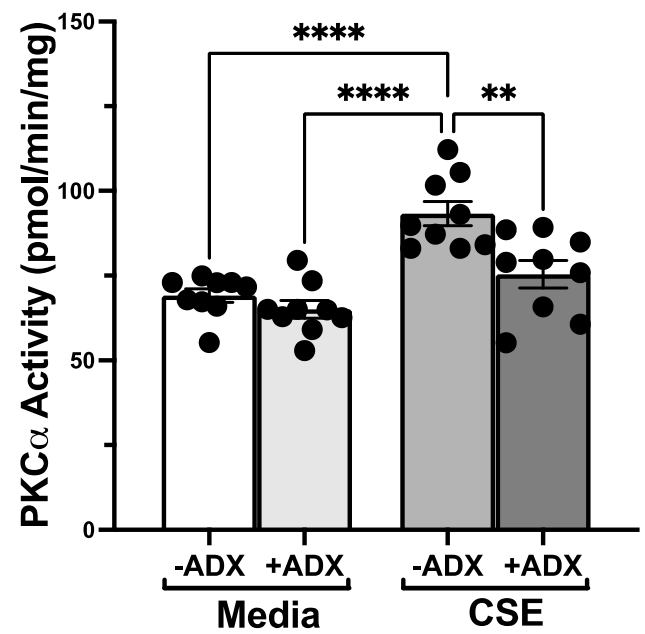

Figure 3. ADX-102 and bronchial epithelial cell protein kinase $C$ alpha (PKC $\alpha$ ) activity. BEAS-2B cells were pretreated with or without $10 \mu \mathrm{M}$ ADX-102 for $1 \mathrm{~h}$ prior to treatment with M-199 containing $10 \%$ serum (Media) or 5\% cigarette smoke extract (CSE) for $1 \mathrm{~h}$. In the absence of ADX-102, ${ }^{* * * *} p<0.0001$ CSE vs. Media. In the presence of CSE, ${ }^{* *} p<0.01$. No ADX vs. ADX. Bars represent SEM of $n=9$, each with three replicates.

A

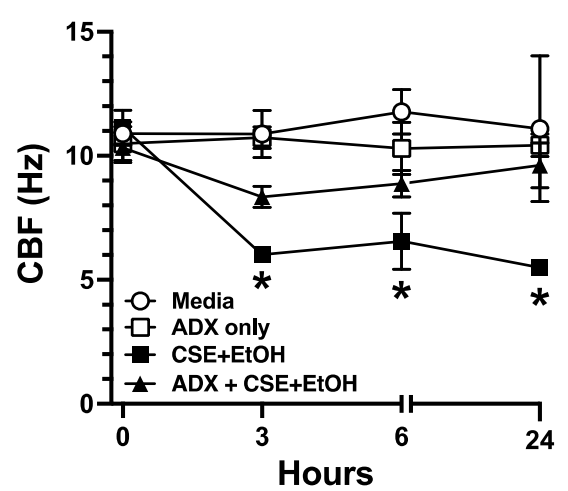

B

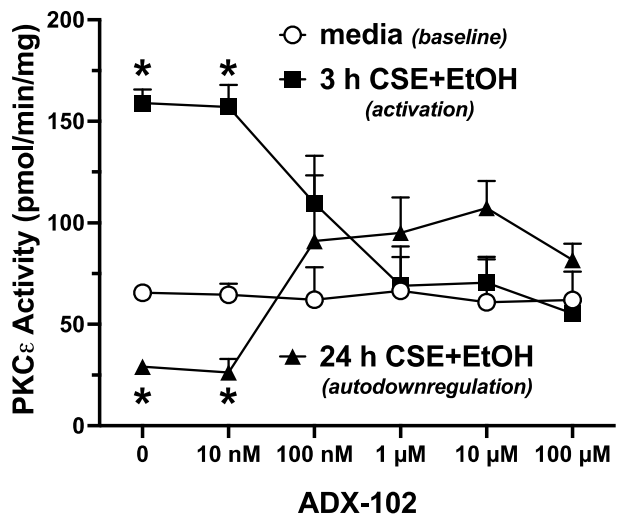

Figure 4. ADX-102 and tracheal epithelial ciliated cell protein kinase C epsilon mediated cilia beating. Ciliated MTECs were treated with or without the combination of $5 \%$ cigarette smoke extract (CSE) and $50 \mathrm{mM}$ ethanol $(\mathrm{EtOH})$ in the presence or absence of $10 \mu \mathrm{M}$ ADX102, and cilia beat frequency (CBF) was measured from 0-24 h (A). Baseline control consisted of DMEM with $10 \%$ serum (Media). ${ }^{*} p<0.05$ ADX vs. no ADX in the presence of $\mathrm{CSE}+\mathrm{EtOH}$ at 3, 6, and $24 \mathrm{~h}$. Dose-response $(0-100 \mu \mathrm{M})$ for ADX-102 on combined CSE and $\mathrm{EtOH}$ stimulated $(3 \mathrm{~h})$ and autodownregulated $(24 \mathrm{~h})$ protein kinase $\mathrm{C}$ epsilon (PKC $\mathrm{E}$ ). * $p<0.01$ vs. medium control. Bars represent SEM of $n=6$, each with three replicates (B).

\subsection{ADX-102 and Cilia Loss}

PKC $\varepsilon$ autodownregulation results in cilia loss and ciliated cell detachment [14]. As we found that ADX-102 prevented smoke and alcohol mediated PKC $\varepsilon$ autodownregulation, we measured the ability of aldehyde trapping to prevent smoke and alcohol induced losses in cilia motility. Using whole-field analysis to capture all the motile points in a 
complete field, no loss of cilia motile points was observed at $3 \mathrm{~h}$ after treatment with smoke and alcohol (when PKCE was catalytically active) (Figure 5A). The average number of moving cilia was similar in both the presence and absence of $10 \mu \mathrm{M}$ of ADX-102 at $3 \mathrm{~h}$ posttreatment. However, by $24 \mathrm{~h}$ posttreatment, PKC $\varepsilon$ was autodownregulated (Figure 4B) and a significant loss in average motile cilia per field was observed (Figure 5B). Cotreatment with $10 \mu \mathrm{M}$ of ADX-102 prevented this loss in motile cilia. Consistent with cell viability data, concentrations of ADX-102 greater than $1 \mathrm{mM}$ resulted in significant cilia loss and nearcomplete ciliated cell detachment when 10 mM of ADX-102 was added (data not shown).
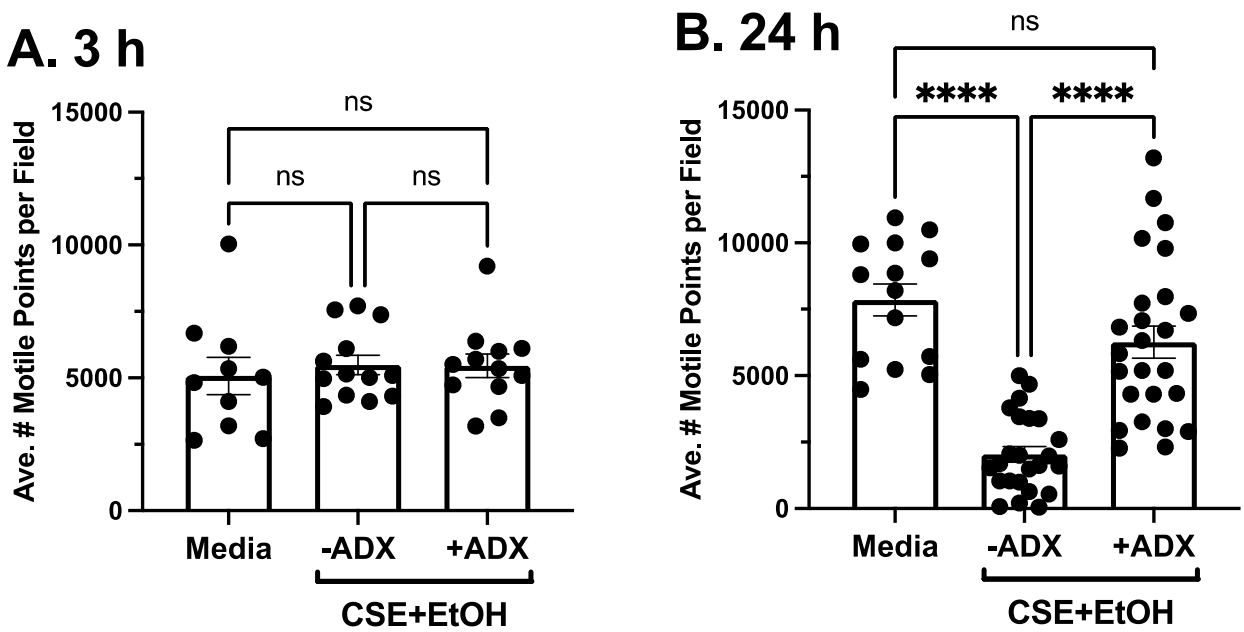

Figure 5. ADX-102 and loss of tracheal epithelial cell cilia. Ciliated MTECs were treated with a combination of $5 \%$ cigarette smoke extract (CSE) and $50 \mathrm{mM}$ ethanol (EtOH) in the presence or absence of $10 \mu \mathrm{M}$ ADX-102, and the average number of motile cilia were measured at $3(\mathrm{~A})$ and $24 \mathrm{~h}(\mathrm{~B}) .{ }^{* * *} p<0.01$ vs. medium control or presence of ADX. Bars represent SEM of at least $n=9$ individual experiments. $\mathrm{ns}=$ not significant.

\subsection{ADX-102 and Barrier Function}

Epithelial cell barrier function is negatively impacted by both cigarette smoke [23] and alcohol [24]. Resistance across a confluent monolayer of $16 \mathrm{HBE}$ cells was significantly decreased by the addition of $5 \%$ CSE at $72 \mathrm{~h}$ (Figure 6A). However, treatment with $50 \mathrm{mM}$ of alcohol or a combination of alcohol and CSE decreased the time of barrier permeability to $\sim 24 \mathrm{~h}$. A $10 \mu \mathrm{M}$ pretreatment with ADX-102 for $1 \mathrm{~h}$ prior to alcohol or CSE exposure prevented this loss of resistance and protected barrier function (Figure 6B). Concentrations of ADX-102 up to $1 \mathrm{mM}$ had no effect on resistance (data not shown).

\subsection{ADX-102 and MAA Adduct Formation}

The co-exposure to cigarette smoke and alcohol generates concentrations of malondialdehyde and acetaldehyde that are required for MAA-adducted protein formation in the lungs [24]. To determine if aldehyde trapping prevents smoke and alcohol induced formation of MAA-adducted protein, 16HBE cells were treated with or without $5 \%$ CSE and $50 \mathrm{mM}$ of alcohol in the presence or absence of $10 \mu \mathrm{M}$ of ADX for $72 \mathrm{~h}$. This combination of CSE and alcohol produced small but significant amounts of MAA-adducted protein (Figure 7). However, in the presence of ADX-102, MAA was significantly decreased in cells treated with CSE and alcohol. No significant amounts of MAA-adducted protein were observed using a control medium or ADX-102 alone. 

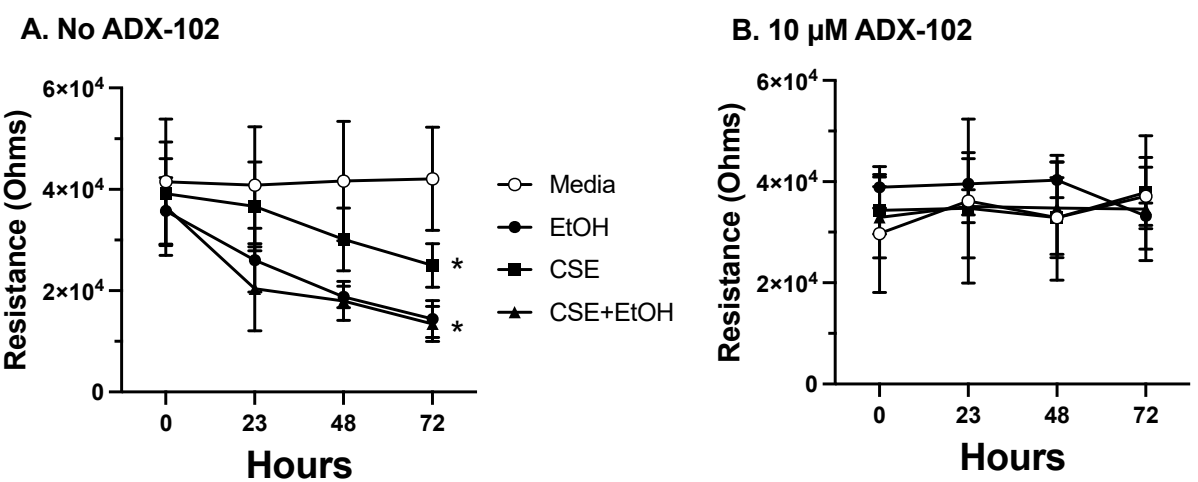

Figure 6. ADX-102 and bronchial epithelial cell permeability. 16HBE cells were grown to confluence until maximal barrier function (Resistance) achieved. Cells were treated with either DMEM and 10\% serum (Media), 5\% cigarette smoke extract (CSE), $50 \mathrm{mM}$ alcohol (EtOH), or the combination of smoke and alcohol for up to $72 \mathrm{~h}$ in the absence (A) or presence (B) of $10 \mu \mathrm{M}$ ADX-102. ${ }^{*} p<0.02$ vs. media at $72 \mathrm{~h}$. Bars represent SEM of $n=5$, each with three replicates.

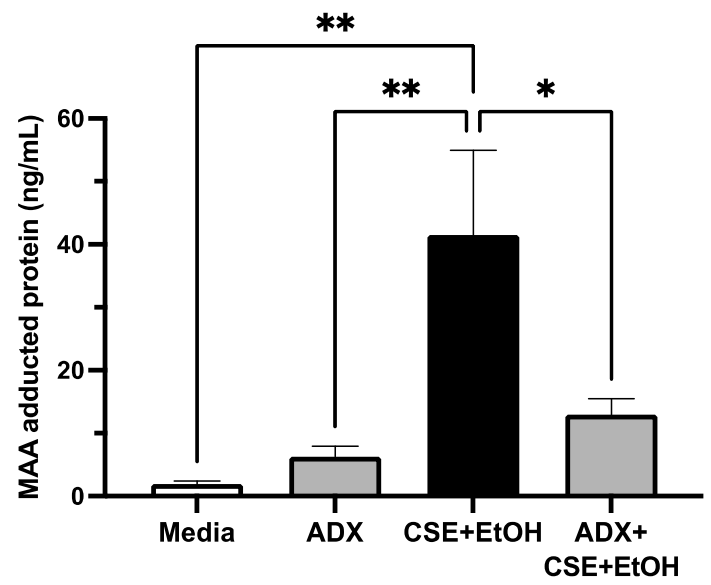

Figure 7. ADX-102 and MAA adduct formation. 16HBE cells were grown to confluence in $60 \mathrm{~mm}$ culture dishes. Cells were treated with either M-199+10\% serum (Media) or a combination of 5\% cigarette smoke extract (CSE) and $50 \mathrm{mM}$ alcohol (EtOH) for $72 \mathrm{~h}$ in the absence or presence of $10 \mu \mathrm{M}$ ADX-102. ${ }^{*} p<0.04$ and ${ }^{* *} p<0.003$ at $72 \mathrm{~h}$. Bars represent SEM of $n=6$.

\section{Discussion}

The lungs are a particularly important target for reactive aldehyde injury in the context of alcohol misuse and cigarette smoking. Alcohol is metabolized into acetaldehyde by alcohol dehydrogenase, and the pyrolysis of tobacco releases large concentrations of acetaldehyde that are directly inhaled by smokers [25]. Lung inflammation induced by reactive oxygen species (ROS) in cigarette smoke produces significant amounts of lipid peroxidation and the formation of malondialdehyde [26]. Similarly, ROS are generated by the metabolism of alcohol through the action of CYP2E1 in the lungs [27]. Acetaldehyde activates PKC $\alpha$ and impairs epithelial cell migration, an important function in reepithelialization in response to repairing a wound [28]. Malondialdehyde and acetaldehyde covalently bind to lysine residues of target proteins via a Schiff base reaction to form stable protein adducts known as MAA adducts [29]. MAA-adducted proteins bind to airway epithelial cells through the CD204 receptor and activate PKCE [30]. Agents that activate $\mathrm{PKC} \varepsilon$ slow cilia and lead to cilia loss or ciliated cell detachment [14]. We showed for the first time that trapping aldehydes with ADX-102 decreases aldehyde-mediated airway epithelial cell injury (Figure 8). 


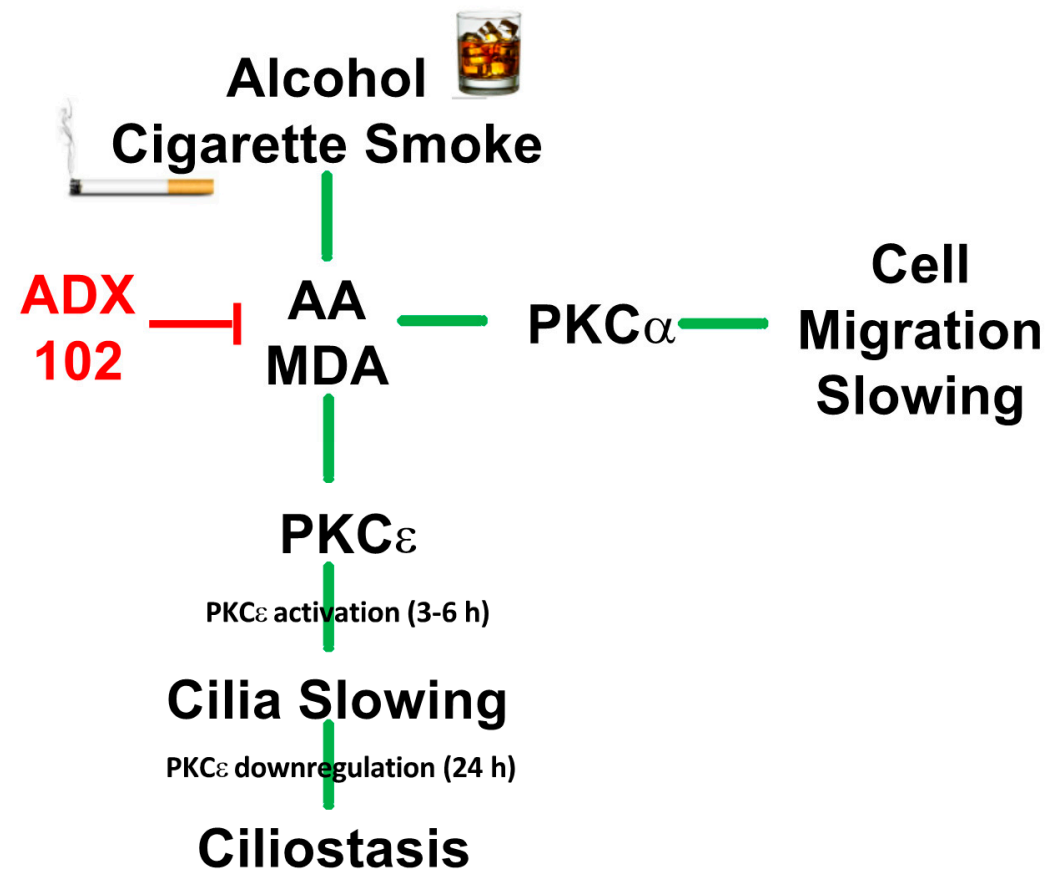

Figure 8. Model diagram for ADX-102 aldehyde-trapping action on cigarette smoke and alcohol mediated injury to airway epithelial cell function.

This study is limited to in vitro observations in airway epithelial cell function. However, these lung cell functions are established models of environmental injury and repair. We utilized three cell types in this study. BEAS-2B cells are optimal for migration studies due to their short passage time but cannot generate cilia for CBF studies and do not form optimal tight junctions for barrier studies. 16HBE cells form excellent tight junctions for barrier studies but do not generate cilia for CBF studies. Primary mouse tracheal epithelial cells can only be cultured in small amounts and grow slowly, but they produce the cilia required for functional studies of CBF. By using the inbred mouse model in this study, human donor variability in the known differential ciliary responses due to environmental exposures, pre-existing lung disease, or age was avoided. Cilia are highly regulable and respond to environmental challenges by increasing their beat frequency to facilitate the effective clearance of particles, microbes, and other pathogens trapped in mucus. However, some agents produce ciliotoxic effects, resulting in a slower cilia beat as well as ciliocytophthoria [31]. Likewise, the impact of a toxin on the maintenance of lung barrier function can be assessed in vitro through measuring resistance across a cell monolayer as a model for potential edematous injury. The repair of an injured epithelial monolayer is governed by the ability of cells to migrate efficiently and rapidly into a wound to facilitate re-epithelialization and the restoration of homeostasis. In each of these models, reactive aldehydes produce such injury through their activation of PKC [32]. We found that ADX-102 inhibits cigarette-smoke-induced delays in cell migration at a lower concentration $(10 \mu \mathrm{M})$ than that required to prevent the slowing of cilia $(100 \mu \mathrm{M})$. This may represent differences in aldehyde activation of the two PKC isoforms that govern these cell functions. In addition, we observed that ADX-102 inhibits smoke and alcohol stimulation of $\mathrm{PKC} \varepsilon>$ at much lower concentrations than those required to prevent the slowing of cilia. This is possibly related to different subcellular populations of PKC $\varepsilon$ in the cell: cilia-localized and cytoplasmic-located kinases [33]. As our catalytic activity assays measured total cellular $\mathrm{PKC} \varepsilon$, the enzyme specifically dedicated to cilia may require a higher ADX-102 concentration for targeting.

Excessive alcohol use is a public health problem that has been defined and measured using a variety of metrics across different cultures and organizations. According to the National Institute on Alcohol Abuse and Alcoholism (NIAAA), Alcohol Use Disorder 
(AUD) is an individual's inability to stop drinking alcohol, despite negative effects, socially, occupationally, or medically [34]. It is measured quantitatively with the Alcohol Use Disorders Identification Test (AUDIT), which is a 10-item screening tool that measures levels of alcohol-related problems [35]. According to the National Survey on Drug Use and Health (NSDUH), in 2019, 14.5 million individuals aged 12 years or older had AUD [36]. The public health burden of alcohol misuse includes the established lung diseases of pneumococcal pneumonia [37], chronic obstructive pulmonary disease [38], and COVID19 [39]. While the established role of alcohol in lung disease is underappreciated, our current understanding of ROS in environmental injury has the potential to open the door to new and innovative clinical therapeutic interventions.

One novel therapeutic approach is the recent development of aldehyde-trapping drugs. The novel reactive aldehyde species (RASP) inhibitor ADX-102, also known as Reproxalap, was recently reported to be safe and effective for the treatment of dry eye disease (DED) $[40,41]$ as well as ocular inflammatory conditions such as noninfectious anterior uveitis and allergic conjunctivitis [15]. Such clinical trials reported that ADX-102 is safe and effective for human use. Although these studies involved topical treatment, delivery using intraperitoneal injection in mice with resulting anti-inflammatory effects was previously reported [42]. Our study represents the first application of an aldehydesequestering compound to address reactive-aldehyde-mediated injury to lung epithelium in vitro. A major limitation of our study is that in vitro cell studies may not translate into the chronic exposure conditions and multifactorial complexities of the in vivo state. As our murine cigarette smoke and alcohol co-exposure model is established [20], translating the findings reported here to an in vivo model is essential to determine whether ADX-102 is useful in protecting against reactive aldehyde lung injury. Further research is required to define any practical implications for ADX-102 as a therapeutic drug for the lungs.

Author Contributions: C.A.O. wrote the manuscript and conducted experiments. C.G.N. made equal contributions to writing and generating data. D.D.M., C.D.B. and D.L.J. conducted experiments and edited the manuscript. K.L.B. and T.A.W. designed, wrote, and edited the manuscript and analyzed data. All authors have read and agreed to the published version of the manuscript.

Funding: C.A.O. was supported by a University of Nebraska medical student research award and a Robert E. Kuhl Testamentary Trust research grant. Additional support was obtained from Central States Center for Agricultural Safety and Health (CS-CASH; U54OH010162 to T.A.W.), VA Merit (I01BX003635 to T.A.W. and I01BX005413 to T.A.W. and K.L.B.), and the National Institute on Aging (R01AG053553 to K.L.B.). T.A.W. is a recipient of a Research Career Scientist Award (IK6BX003781) from the Department of Veterans Affairs. D.L.J. was supported by the National Institute on Alcoholism and Alcohol Abuse Summer Undergraduate Alcohol Research Program (R25AA020818).

Institutional Review Board Statement: This study did not include human subjects. The use of mice was conducted according to the Department of Health and Human Services' Public Health Service (PHS) policy on Humane Care and Use of Laboratory Animals and was reviewed and approved by the Institutional Animal Care and Use Committee of the University of Nebraska Medical Center (protocol numbers: 16-136-11 and 19-021-04).

Informed Consent Statement: This study did not include human subjects.

Data Availability Statement: The data presented in this manuscript are available upon request from the corresponding author.

Conflicts of Interest: The authors declare no conflict of interest. The authors alone are responsible for the content of this manuscript.

\section{References}

1. Office on Smoking and Health, Centers for Disease Control and Prevention, Smoking \& Tobacco Use: Fast Facts. Available online: https://www.cdc.gov/tobacco/data_statistics/fact_sheets/fast_facts/index.htm\#beginning (accessed on 5 October 2021).

2. Romberger, D.J.; Grant, K. Alcohol consumption and smoking status: The role of smoking cessation. Biomed. Pharmacother. 2004, 58,77-83. [CrossRef] 
3. Chudomelka, L.; Wyatt, T.A. Cross-fading: The importance of tissue injury research on dual misuse of alcohol and JUUL. Alcohol 2020, 86, 43-44. [CrossRef] [PubMed]

4. Joshi, P.C.; Applewhite, L.; Ritzenthaler, J.D.; Roman, J.; Fernandez, A.L.; Eaton, D.C.; Brown, L.A.; Guidot, D.M. Chronic ethanol ingestion in rats decreases granulocyte-macrophage colony-stimulating factor receptor expression and downstream signaling in the alveolar macrophage. J. Immunol. 2005, 175, 6837-6845. [CrossRef]

5. Simet, S.M.; Sisson, J.H. Alcohol's Effects on Lung Health and Immunity. Alcohol Res. 2015, 37, 199-208. [PubMed]

6. Boé, D.M.; Vandivier, R.W.; Burnham, E.L.; Moss, M. Alcohol abuse and pulmonary disease. J. Leukoc. Biol. 2009, 86, 1097-1104. [CrossRef] [PubMed]

7. Kaphalia, L.; Calhoun, W.J. Alcoholic lung injury: Metabolic, biochemical and immunological aspects. Toxicol. Lett. 2013, 222, 171-179. [CrossRef] [PubMed]

8. Cederbaum, A.I. Role of CYP2E1 in ethanol-induced oxidant stress, fatty liver and hepatotoxicity. Dig. Dis. 2010, 28, 802-811. [CrossRef]

9. National Institute on Alcohol Abuse and Alcoholism, Alcohol Facts and Statistics. Available online: https://www.niaaa.nih.gov/ publications/brochures-and-fact-sheets/alcohol-facts-and-statistics (accessed on 29 March 2021).

10. Fujioka, K.; Shibamoto, T. Determination of toxic carbonyl compounds in cigarette smoke. Environ. Toxicol. 2006, 21, 47-54 [CrossRef]

11. Weng, M.W.; Lee, H.W.; Park, S.H.; Hu, Y.; Wang, H.T.; Chen, L.C.; Rom, W.N.; Huang, W.C.; Lepor, H.; Wu, X.R.; et al. Aldehydes are the predominant forces inducing DNA damage and inhibiting DNA repair in tobacco smoke carcinogenesis. Proc. Natl. Acad. Sci. USA 2018, 115, E6152-E6161. [CrossRef]

12. McCaskill, M.L.; Kharbanda, K.K.; Tuma, D.J.; Reynolds, J.D.; DeVasure, J.M.; Sisson, J.H.; Wyatt, T.A. Hybrid malondialdehyde and acetaldehyde protein adducts form in the lungs of mice exposed to alcohol and cigarette smoke. Alcohol Clin. Exp. Res. 2011, 35, 1106-1113. [CrossRef]

13. Wyatt, T.A.; Kharbanda, K.K.; Tuma, D.J.; Sisson, J.H.; Spurzem, J.R. Malondialdehyde-acetaldehyde adducts decrease bronchial epithelial wound repair. Alcohol 2005, 36, 31-40. [CrossRef] [PubMed]

14. Wyatt, T.A.; Sisson, J.H.; Allen-Gipson, D.S.; McCaskill, M.L.; Boten, J.A.; DeVasure, J.M.; Bailey, K.L.; Poole, J.A. Co-exposure to cigarette smoke and alcohol decreases airway epithelial cell cilia beating in a protein kinase Cepsilon-dependent manner. Am. J. Pathol. 2012, 181, 431-440. [CrossRef] [PubMed]

15. Aldeyra Therapeutics, Inc. Dry Eye Disease. Available online: https://www.aldeyra.com/pipeline-disease-areas/oculardiseases/dry-eye-disease/ (accessed on 8 September 2021).

16. Dossou, S.J.; Bré, M.H.; Hallworth, R. Mammalian cilia function is independent of the polymeric state of tubulin glycylation. Cell Motil. Cytoskelet 2007, 64, 847-855. [CrossRef] [PubMed]

17. Cantral, D.E.; Sisson, J.H.; Veys, T.; Rennard, S.I.; Spurzem, J.R. Effects of cigarette smoke extract on bovine bronchial epithelial cell attachment and migration. Am. J. Physiol.-Lung Cell. Mol. Physiol. 1995, 268, L723-L728. [CrossRef]

18. Allen-Gipson, D.S.; Wong, J.; Spurzem, J.R.; Sisson, J.H.; Wyatt, T.A. Adenosine A2A receptors promote adenosine-stimulated wound healing in bronchial epithelial cells. Am. J. Physiol.-Lung Cell. Mol. Physiol. 2006, 290, L849-L855. [CrossRef]

19. Spurzem, J.R.; Gupta, J.; Veys, T.; Kneifl, K.R.; Rennard, S.I.; Wyatt, T.A. Activation of protein kinase A accelerates bovine bronchial epithelial cell migration. Am. J. Physiol.-Lung Cell. Mol. Physiol. 2002, 282, L1108-L1116. [CrossRef]

20. Elliott, M.K.; Sisson, J.H.; Wyatt, T.A. Effects of cigarette smoke and alcohol on ciliated tracheal epithelium and inflammatory cell recruitment. Am. J. Respir. Cell Mol. Biol. 2007, 36, 452-459. [CrossRef]

21. Sisson, J.H.; Stoner, J.A.; Ammons, B.A.; Wyatt, T.A. All-digital image capture and whole-field analysis of ciliary beat frequency. J. Microsc. 2003, 211, 103-111. [CrossRef]

22. Wyatt, T.A.; Schmidt, S.C.; Rennard, S.I.; Tuma, D.J.; Sisson, J.H. Acetaldehyde-stimulated PKC activity in airway epithelial cells treated with smoke extract from normal and smokeless cigarettes. Proc. Soc. Exp. Biol. Med. 2000, 225, 91-97. [CrossRef]

23. Olivera, D.S.; Boggs, S.E.; Beenhouwer, C.; Aden, J.; Knall, C. Cellular mechanisms of mainstream cigarette smoke-induced lung epithelial tight junction permeability changes in vitro. Inhal. Toxicol. 2007, 19, 13-22. [CrossRef]

24. Schlingmann, B.; Overgaard, C.E.; Molina, S.A.; Lynn, K.S.; Mitchell, L.A.; Dorsainvil White, S.; Mattheyses, A.L.; Guidot, D.M.; Capaldo, C.T.; Koval, M. Regulation of claudin/zonula occludens-1 complexes by hetero-claudin interactions. Nat. Commun. 2016, 7, 12276. [CrossRef] [PubMed]

25. Sapkota, M.; Burnham, E.L.; DeVasure, J.M.; Sweeter, J.M.; Hunter, C.D.; Duryee, M.J.; Klassen, L.W.; Kharbanda, K.K.; Sisson, J.H.; Thiele, G.M.; et al. Malondialdehyde-Acetaldehyde (MAA) Protein Adducts Are Found Exclusively in the Lungs of Smokers with Alcohol Use Disorders and Are Associated with Systemic Anti-MAA Antibodies. Alcohol Clin. Exp. Res. 2017, 41, 2093-2099. [CrossRef] [PubMed]

26. Altuntaş, I.; Dane, S.; Gümüş̧tekin, K. Effects of cigarette smoking on lipid peroxidation. J. Basic Clin. Physiol. Pharmacol. 2002, 13, 69-72. [CrossRef] [PubMed]

27. Runge, D.M.; Stock, T.W.; Lehmann, T.; Taege, C.; Bernauer, U.; Stolz, D.B.; Hofmann, S.; Foth, H. Expression of cytochrome P450 2E1 in normal human bronchial epithelial cells and activation by ethanol in culture. Arch. Toxicol. 2001, 75, 335-345. [CrossRef]

28. van der Vliet, A.; Bove, P.F. Purinergic signaling in wound healing and airway remodeling. Subcell. Biochem. 2011, 55, 139-157. [CrossRef] 
29. Thiele, G.M.; Worrall, S.; Tuma, D.J.; Klassen, L.W.; Wyatt, T.A.; Nagata, N. The chemistry and biological effects of malondialdehyde-acetaldehyde adducts. Alcohol Clin. Exp. Res. 2001, 25, 218S-224S. [CrossRef]

30. Berger, J.P.; Simet, S.M.; DeVasure, J.M.; Boten, J.A.; Sweeter, J.M.; Kharbanda, K.K.; Sisson, J.H.; Wyatt, T.A. Malondialdehydeacetaldehyde (MAA) adducted proteins bind to scavenger receptor A in airway epithelial cells. Alcohol 2014, 48, 493-500. [CrossRef]

31. Rosenblatt, M.B.; Trinidad, S.; Lisa, J.R.; Tchertkoff, V. Specific epithelial degeneration (ciliocytophthoria) in inflammatory and malignant respiratory disease. Dis. Chest. 1963, 43, 605-612. [CrossRef]

32. Sapkota, M.; Wyatt, T.A. Alcohol, Aldehydes, Adducts and Airways. Biomolecules 2015, 5, 2987-3008. [CrossRef]

33. Slager, R.E.; Devasure, J.M.; Pavlik, J.A.; Sisson, J.H.; Wyatt, T.A. RACK1, a PKC targeting protein, is exclusively localized to basal airway epithelial cells. J. Histochem. Cytochem. 2008, 56, 7-14. [CrossRef]

34. National Institute on Alcohol Abuse and Alcoholism, Understanding Alcohol Use Disorders. Available online: https://www niaaa.nih.gov/publications/brochures-and-fact-sheets/understanding-alcohol-use-disorder (accessed on 8 September 2021).

35. National Institue on Drug Abuse, AUDIT. Available online: https://www.drugabuse.gov/sites/default/files/audit.pdf (accessed on 8 September 2021).

36. Substance Abuse and Mental Health Services Administration, U.S. Department of Health and Human Services. 2019 NSDUH Detailed Tables. Available online: https:/ / www.samhsa.gov/data/release/2019-national-survey-drug-use-and-health-nsduhreleases (accessed on 8 September 2021).

37. Gentry, M.J. Pneumococcal pneumonia in alcoholism and HIV infection. Alcohol Clin. Exp. Res. 1998, 22, 201s-203s. [CrossRef] [PubMed]

38. Tabak, C.; Smit, H.A.; Rasanen, L.; Fidanza, F.; Menotti, A.; Nissinen, A.; Feskens, E.J.; Heederik, D.; Kromhout, D. Alcohol consumption in relation to 20-year COPD mortality and pulmonary function in middle-aged men from three European countries. Epidemiology 2001, 12, 239-245. [CrossRef] [PubMed]

39. Bailey, K.L.; Samuelson, D.R.; Wyatt, T.A. Alcohol use disorder: A pre-existing condition for COVID-19? Alcohol 2021, 90, 11-17. [CrossRef] [PubMed]

40. Clark, D.; Cavanagh, B.; Shields, A.L.; Karpecki, P.; Sheppard, J.; Brady, T.C. Clinically Relevant Activity of the Novel RASP Inhibitor Reproxalap in Allergic Conjunctivitis: The Phase 3 ALLEVIATE Trial. Am. J. Ophthalmol. 2021, 230, 60-67. [CrossRef]

41. Clark, D.; Sheppard, J.; Brady, T.C. A Randomized Double-Masked Phase 2a Trial to Evaluate Activity and Safety of Topical Ocular Reproxalap, a Novel RASP Inhibitor, in Dry Eye Disease. J. Ocul. Pharmacol. Ther. 2021, 37, 193-199. [CrossRef]

42. MacDonald, S.; Halilovic, A.; Brady, T. Novel Small Molecule Aldehyde Sequestering Agents Demonstrate Broad Therapeutic Potential for Ocular Inflammation. Investig. Ophthalmol. Vis. Sci. 2018, 59, 2663. 